\title{
Biological disease-modifying antirheumatic drugs in juvenile idiopathic arthritis of polyarticular course, enthesitis-related arthritis, and psoriatic arthritis: a consensus statement
}

\author{
Assunta CH Ho *, SN Wong, Lettie CK Leung, Winnie KY Chan, Patrick CY Chong, Niko KC Tse, \\ Roanna HM Yeung, SY Kong, KP Lee
}

\section{A B S T R A C T}

Objectives: Juvenile idiopathic arthritis (JIA) is the most common type of inflammatory arthritis in children. Treatment options have been expanded since the introduction of biologics, which are highly effective. The existing local JIA treatment guideline was published more than a decade ago, when use of biologics was not as common. In this article, we review the latest evidence on using biologics in three JIA subtypes: JIA of polyarticular course (pcJIA), enthesitis-related arthritis (ERA), and psoriatic arthritis (PsA). Based on the latest information, an update on eligibility, response assessment, termination, and safety information for using biologics in these patients was performed.

Consensus process: The JIA Work Group, which consisted of nine paediatricians experienced in managing JIA, was convened in 2016. Publications before July 2017 were screened. Eligible articles were clinical trials, extension studies, systemic reviews, and recommendations from international societies and regulatory agencies about the use of biologics in pcJIA, ERA, and PsA. Evidence extraction, appraisal, and drafting of propositions were performed by two reviewers. Extracted evidence and drafted propositions were presented and discussed at the first two meetings. Overwhelming consensus was obtained at the final meeting in May 2018. Seven practice consensus statements were formulated. Regular review should be performed to keep the practice evidence-based and up-to-date.

Hong Kong Med J 2020;26:56-65 https://doi.org/10.12809/hkmj198195
${ }^{1} \mathrm{ACH} \mathrm{Ho}$ *, MB, ChB, FHKAM (Paediatrics)
${ }^{2}$ SN Wong, MB, BS, FHKAM (Paediatrics)
${ }^{3}$ LCK Leung, MB, BS (Syd), FHKAM (Paediatrics)
${ }^{4}$ WKY Chan, MB, BS, FHKAM (Paediatrics)
${ }^{5}$ PCY Chong, MB, BS, FHKAM (Paediatrics)
${ }^{6}$ NKC Tse, MB, BS, FHKAM (Paediatrics)
${ }^{4}$ RHM Yeung, MB, BS, FHKAM (Paediatrics)
${ }^{3}$ SY Kong, MB, ChB, FHKAM (Paediatrics)
${ }^{7}$ KP Lee, MB, ChB, FHKAM (Paediatrics)

${ }^{1}$ Department of Paediatrics, Prince of Wales Hospital, The Chinese University of Hong Kong, Shatin, Hong Kong

Department of Paediatrics and Adolescent Medicine, Tuen Mun Hospital, Tuen Mun, Hong Kong

${ }^{3}$ Department of Paediatrics, Kwong Wah Hospital, Yaumatei, Hong Kong

${ }^{4}$ Department of Paediatrics, Queen Elizabeth Hospital, Jordan, Hong Kong

Department of Paediatrics and Adolescent Medicine, Queen Mary Hospital, The University of Hong Kong, Pokfulam, Hong Kong

Department of Paediatrics and Adolescent Medicine, Princess Margaret Hospital, Laichikok, Hong Kong

Department of Paediatrics and Adolescent Medicine, Pamela Youde Nethersole Eastern Hospital, Chai Wan, Hong Kong

* Corresponding author: assuntaho@cuhk.edu.hk

\section{Introduction}

Biological disease-modifying antirheumatic drugs (DMARDs) were introduced for the treatment of juvenile idiopathic arthritis (JIA) in year 2000. They are highly effective, especially for patients who are refractory to conventional DMARDs (cDMARDs). The current treatment algorithm for JIA in Hong Kong was published more than a decade ago, when the use of biologics was not as common. ${ }^{1}$ There has been a huge expansion in knowledge and approved medications since then. An update of practice based on the latest evidence is required, not only for specialists but also paediatricians and family physicians who may provide care to children with JIA.

The Hong Kong Society for Paediatric
Rheumatology commissioned the JIA Work Group in 2016 to review this topic. The work group consists of nine paediatricians experienced in managing JIA. Our aims were: (1) to review the latest evidence on biological DMARDs in polyarticular course JIA (pcJIA, ie, those having arthritis affecting $\geq 5$ joints irrespective of subtype at onset), enthesitis-related arthritis (ERA), and psoriatic arthritis (PsA); and (2) to propose an updated practice consensus for using biologics in these patients.

\section{Methods}

Articles about the use of biologics in pcJIA, ERA, and PsA published in English before July 2017 were identified by searching MEDLINE and PubMed. The keywords used for searching included JIA, 
pcJIA, ERA, PsA, eoJIA (extended oligoarticular arthritis), biologics, biological DMARDs, guidelines, recommendation, practice review, registries, adverse effects, malignancy, and infection. Publications considered relevant were clinical trials (randomised trials, reports on long-term extension phase of clinical trials), open-label studies, results from analysis of major registries, and recommendations from international regulatory organisations (United Kingdom: Clinical Commissioning Policy of National Health Service, National Institute for Health and Care Excellence; United States: American College of Rheumatology [ACR]; Australia: the Pharmaceutical Benefits Scheme, reimbursement programme for biologics use). Article screening, grading of the level of evidence, and propositions drafting were performed by two reviewers. The extracted evidence and draft propositions were presented to work group members at the first meeting held in July 2017. They were discussed and deliberated in a subsequent meeting held in March 2018. At the final meeting in May 2018, overwhelming consensus was reached on seven practice consensus statements.

\section{Statement 1: Level of care}

Care of children with JIA should preferably be shared jointly with paediatricians experienced in managing JIA.

With modern treatment strategies, a high level of disease control is possible. One study reported that more than $70 \%$ of patients (except rheumatoid factor positive polyarticular JIA) were able to reach a clinically inactive disease state within 2 years. ${ }^{2}$ To achieve the best outcome, care plans and treatment targets should be carefully formulated together with patients and paediatricians experienced in managing JIA.

\section{Statement 2: Therapeutic ladder}

For pcJIA, ERA and PsA, patients with persistently active arthritis despite adequate use of one or more cDMARDs, or if patients are intolerant of them, treatment escalation to biological DMARDs should be considered.

Conventional DMARDs like methotrexate, leflunomide, and sulphasalazine are effective in treating pcJIA..$^{3-6}$ The choice of cDMARDs usually depends on JIA subtype and patient tolerance. Nevertheless, some patients may not respond to or may be intolerant of cDMARDs. Switching to biologics should be considered in these cases.

\section{Biological disease-modifying antirheumatic drugs: evidence of effectiveness}

\section{Anti-tumour necrosis factor inhibitors}

\section{Etanercept}

Etanercept is a chimeric fusion protein that acts

\section{有關生物製劑於多關節型的幼年突發性關節炎、 附着點炎症相關關節炎及銀屑病關節炎的運用： 共識聲明}

\author{
何志恆、黃錫年、梁竹筠、陳桂如、莊俊賢、謝紀超、 \\ 楊凱旻、江心怡、李國彪
}

目的：幼年突發性關節炎(簡稱JIA)是最常見的兒童關節炎。隨着生 物製劑的引入, 現代的治療方案比過往更有效。本港上一份治療方 案沿用至今已有十多年, 那時生物製劑的使用並未普遍。本文探討 生物製劑於三款關節炎的使用，包括多關節型的幼年突發性關節炎 (polyarticular course JIA)、附着點炎症相關關節炎 (enthesitis related arthritis，ERA）及銀屑病關節炎（psoriatic arthritis，PsA）。本文亦 會根據最新的科研資料及參考國際權威機構的治療建議, 提供最新的 治療準則。

共識過程：九位富有治療關節炎經驗的兒科醫生於2016年組成工作小 組。小組分析 2017 年7月前刊載的相關文獻、研究論文、著萃分析、 指南及共識聲明, 並在會議前預備共識聲明草案。經過兩次會議及討 論, 小組最終確定七項共識聲明。此聲明須定期檢視最新證據以及更 新。

as soluble TNF receptor. It is approved for use in cases of: (1) pcJIA in children aged $\geq 2$ years (Food and Drug Administration [FDA] and European Medicines Agency [EMA]) and (2) ERA and PsA in children aged $\geq 12$ years (EMA). The dose is $0.4 \mathrm{mg} / \mathrm{kg}$ (max $25 \mathrm{mg}$ ) twice weekly or $0.8 \mathrm{mg} / \mathrm{kg}$ ( $\max 50 \mathrm{mg}$ ) once weekly subcutaneously.

Etanercept was the first anti-TNF inhibitor approved for pcJIA. Its efficacy was demonstrated by a randomised withdrawal trial ${ }^{7}$, in which 69 patients with pcJIA aged 4 to 17 years who were refractory to methotrexate were enrolled in the open-label lead-in phase. Fifty one (74\%) patients achieved an ACR 30 response at week 12 . They were then randomised to receive either etanercept or placebo for 16 weeks. Etanercept was more effective in preventing arthritis flares $(28 \%$ vs $81 \%, \mathrm{P}=0.003)$. The median time to flare was significantly shorter in the placebo group (28 days vs 116 days, $\mathrm{P}<0.001$ ). Long-term data from the extension phase confirmed the persistence of efficacy. ${ }^{8}$

The use of etanercept in eoJIA, ERA, and PsA was studied by Horneff et al. ${ }^{9}$ In all, 127 patients (60 patients with eoJIA aged 2-17 years, 38 patients with ERA aged 12-17 years, 29 patients with PsA aged 12-17 years) were recruited in an open-label multicentre study. All had persistently active disease despite the use of nonsteroidal anti-inflammatory drugs (NSAIDs; for ERA) and DMARDs (for eoJIA, ERA, and PsA). At week 12, 88.6\% (95\% confidence interval $[C I]=81.6 \%-93.6 \%)$ had attained ACR 30 response. The proportion of response was similar across all three subtypes. 
The efficacy of etanercept in ERA was further evaluated. In a phase III double-blinded study, 41 patients aged 6 to 17 years with active disease despite taking at least one NSAID and one DMARD were recruited. They received open-label etanercept for 24 weeks. An ACR 30 response was achieved in 38 (93\%). These patients were then randomised to receive etanercept or placebo in the subsequent 24-week withdrawal phase. The odds for having a flare was significantly higher in placebo group (odds ratio $=6,95 \% \mathrm{CI}=1.1-37, \mathrm{P}=0.02) .{ }^{10}$

The use of etanercept has now been extended to 2 years old. ${ }^{11}$ The efficacy of administrating at 0.8 $\mathrm{mg} / \mathrm{kg}$ weekly has been shown to be comparable to twice weekly dosing. ${ }^{12}$

Etanercept can be used concomitantly with methotrexate or as monotherapy. ${ }^{13}$

\section{Adalimumab}

Adalimumab is a fully humanised monoclonal antiTNF antibody. It is approved for use in cases of: (1) pc)IA in children aged $\geq 2$ years (FDA and EMA) and (2) ERA in children aged $\geq 6$ years (EMA). The dose is once every other week at $10 \mathrm{mg}$ for 10 to $<15 \mathrm{~kg}, 20$ $\mathrm{mg}$ for 15 to $<30 \mathrm{~kg}$, and $40 \mathrm{mg}$ for $\geq 30 \mathrm{~kg}$.

Adalimumab was shown to be effective in treating pcJIA by Lovell et al..$^{14}$ In total, 171 patients aged 4 to 17 years with active arthritis despite taking NSAIDs or methotrexate were enrolled in the 16-week open-label phase. In all, 94\% of the adalimumab-methotrexate group and $74 \%$ of the adalimumab monotherapy group demonstrated an ACR 30 response. In the 32-week randomised withdrawal phase, the flare rate was significantly lower for those who remained on adalimumab. The results were more pronounced in patients receiving concomitant methotrexate (flare in placebo and methotrexate vs adalimumab and methotrexate: $65 \%$ vs $37 \%, \mathrm{P}=0.02$; flare in placebo vs adalimumab: $71 \%$ vs $43 \%, \mathrm{P}=0.03)$. Efficacy was maintained in the longterm extension phase.

Burgos-Vargas et a $\mathrm{l}^{15}$ studied the effectiveness of adalimumab in 46 patients with ERA. These patients, aged 6 to 17 years, had active arthritis and enthesitis. They were randomised to receive either adalimumab or placebo. At week 12, the adalimumab group had a significantly greater percentage decrease in the number of active joints $(-62.2 \%$ vs $-11.6 \%$, $\mathrm{P}=0.039$ ).

The safety and effectiveness of adalimumab in children aged 2 to 4 years weighing $<15 \mathrm{~kg}$ were also demonstrated..$^{16}$

Adalimumab can be used together with methotrexate or as monotherapy.

\section{T cell co-stimulation inhibitor}

\section{Abatacept}

Abatacept is a co-stimulation modulator that binds to the cluster of differentiation (CD) 80 or CD 86 ligands of the antigen-presenting cell and interferes with its interactions with $\mathrm{T}$ cells. Abatacept is indicated for pcJIA in children aged $\geq 6$ years who are unresponsive to cDMARDs and at least one antiTNF (EMA, FDA). The dose is $10 \mathrm{mg} / \mathrm{kg}$ ( $\max 1 \mathrm{~g}$ ) infusion on day $1,15,29$, and then every 28 days.

The efficacy of abatacept in pcJIA was assessed in a randomised withdrawal trial by Ruperto et al. ${ }^{17}$ The enrolled patients were aged 6 to 17 years with active disease despite DMARDs including anti-TNF inhibitors. Systemic JIA patients without systemic manifestations were also eligible. Patients with ERA or PsA were not included. Among the 190 recruited patients, $27 \%$ had previously been exposed to antiTNF therapy. At the end of the 4-month open-label phase, 123 (65\%) demonstrated an ACR 30 response. After one patient left the study, the remaining 122 patients were randomised to receive abatacept (60 patients) or placebo (62 patients) for 6 months. The flare rate of the abatacept group was significantly lower than that of the placebo group $(20 \%$ vs $53 \%$, $\mathrm{P}=0.0003)$. The hazard ratio for having a flare in the abatacept group was 0.31 (95\% CI=0.16-0.95). The median time to flare was 6 months for placebo and not assessable for abatacept because of an inadequate number of events $(\mathrm{P}=0.0002)$. Among patients who did not achieve ACR 30 at the end of the 4-month open-label phase, half achieved ACR 30 after longer exposure. By day 589 of the long-term extension phase, the proportions of patients achieving ACR $30,50,70,90$, and 100 were $90 \%, 88 \%, 75 \%, 57 \%$, and $39 \%$, respectively. ${ }^{18}$

Abatacept can be used concomitantly with methotrexate or as monotherapy.

\section{Anti-interleukin 6 inhibitor}

\section{Tocilizumab}

Tocilizumab is a humanised anti-interleukin 6 monoclonal antibody. It is indicated for pcJIA in child aged $\geq 2$ years (FDA, EMA). The dose is once every 4 weeks intravenous infusion, $10 \mathrm{mg} / \mathrm{kg}$ for $<30 \mathrm{~kg}, 8 \mathrm{mg} / \mathrm{kg}$ for $\geq 30 \mathrm{~kg}$.

Tocilizumab is another non-anti-TNF option for pcJIA. In a phase 3, three-part randomised controlled study (CHERISH), 188 patients aged 2 to 17 years with active disease received openlabel tocilizumab for 16 weeks. In all, $166(88 \%)$ achieved an ACR 30 response. A total of 163 were then randomised to receive tocilizumab $(n=82)$ or placebo $(n=81)$ for 24 weeks. Flares of JIA occurred significantly less often in the tocilizumab group (25.6\% vs $48.1 \%$, difference in means adjusted for stratification $-0.21 ; 95 \% \mathrm{CI}=-0.35$ to -0.08 ; $\mathrm{P}=0.0024)$. Numerically more patients on concurrent methotrexate achieved ACR 70 and 90 responses. ${ }^{19}$

Tocilizumab can be used concomitantly with methotrexate or as monotherapy. 
TABLE I. Summary of trails on individual biologics for pcJIA, ERA, and PsA

\begin{tabular}{|c|c|c|c|c|c|c|c|}
\hline $\begin{array}{l}\text { Author, } \\
\text { year }\end{array}$ & $\begin{array}{l}\text { Study design, } \\
\text { sample size, } \\
\text { duration }\end{array}$ & $\begin{array}{l}\text { Drugs, } \\
\text { comparator }\end{array}$ & Population & Concomitant MTX & Primary outcome & Results & $\begin{array}{l}\text { Level of } \\
\text { evidence* }\end{array}$ \\
\hline $\begin{array}{l}\text { Lovell, } \\
2000^{7}\end{array}$ & $\begin{array}{l}\text { 12-week open-label } \\
\text { lead-in phase, } n=69 \\
16 \text {-week } \\
\text { randomised } \\
\text { withdrawal trial for } \\
\text { those who achieved } \\
\text { ACR } 30, n=51\end{array}$ & $\begin{array}{l}\text { Etanercept sc } 0.4 \\
\mathrm{mg} / \mathrm{kg} / \mathrm{dose} \\
2 \times / \text { week } \\
\text { Max } 25 \mathrm{mg} \\
\text { vs placebo }\end{array}$ & $\begin{array}{l}\text { pcJIA (eoJIA, PJIA, } \\
\text { SJIA) } \\
\text { Aged 4-17 years } \\
\text { Active polyarthritis } \\
\text { despite MTx } \geq 10 \\
\mathrm{mg} / \mathrm{m}^{2} / \text { week (active } \\
\text { arthritis: } \geq 5 \text { swollen } \\
\text { and } \geq 3 \text { LOM) }\end{array}$ & No & $\begin{array}{l}\text { No. of patients } \\
\text { with disease flare } \\
\text { during randomised } \\
\text { withdrawal phase }\end{array}$ & $\begin{array}{l}\text { Placebo } 81 \% \text { ( } 21 \\
\text { of } 26) \text { vs etanercept } \\
28 \%(7 \text { of } 25), \\
P=0.003\end{array}$ & 2 \\
\hline $\begin{array}{l}\text { Horneff, } \\
2014^{9}\end{array}$ & $\begin{array}{l}\text { 12-week open-label } \\
\text { study, } n=127 \text { ( } 60 \\
\text { eoJIA, } 38 \text { ERA, } 29 \\
\text { PsA) }\end{array}$ & $\begin{array}{l}\text { Etanercept sc } 0.8 \\
\mathrm{mg} / \mathrm{kg} / \text { week, max } \\
50 \mathrm{mg}\end{array}$ & $\begin{array}{l}\text { eoJIA: aged 2-17 } \\
\text { years } \\
\text { ERA and PsA: aged } \\
12-17 \text { years } \\
\text { Active disease: } \geq 2 \\
\text { active joints, history } \\
\text { of intolerance or } \\
\text { unsatisfactory } \\
\text { response to at least } 3 \\
\text { months of } \geq 1 \text { DMARD } \\
\text { or, only for ERA, at } \\
\text { least } 1 \text { month of } \geq 1 \\
\text { NSAID }\end{array}$ & $\begin{array}{l}\text { Allowed (one of the } \\
\text { following allowed: } \\
\text { MTx, SSZ, HCQ, } \\
\text { chloroquine) }\end{array}$ & $\begin{array}{l}\text { Percentage of } \\
\text { patients achieving } \\
\text { JIA ACR } 30 \text { at week } \\
12\end{array}$ & $\begin{array}{l}\text { Overall: 88.6\% (95\% } \\
\text { Cl=81.6\%-93.6\%) } \\
\text { eoJIA: 89.7\% (95\% } \\
\text { Cl=78.8\%-96.1\%) } \\
\text { ERA: } 83.3 \%(95 \% \\
\text { Cl=67.2\%-93.6\%) } \\
\text { PsA: 93.1\% (95\% } \\
\text { Cl=77.2\%-99.2\%) }\end{array}$ & 3 \\
\hline $\begin{array}{l}\text { Horneff, } \\
2015^{10}\end{array}$ & $\begin{array}{l}\text { 24-week open-label } \\
\text { lead-in phase, } n=41 \\
\text { 24-week } \\
\text { randomised } \\
\text { withdrawal trial for } \\
\text { those who achieved } \\
\text { ACR Pedi } 30, n=38\end{array}$ & $\begin{array}{l}\text { Etanercept sc } \\
0.8 \mathrm{mg} / \mathrm{kg} / \mathrm{week} \\
\text { Max } 50 \mathrm{mg} \\
\text { vs placebo }\end{array}$ & $\begin{array}{l}\text { ERA, aged 6-17 years } \\
\text { Active disease: } \geq 3 \\
\text { active joints (swollen } \\
\text { or LOM), NRS } \geq 3 \\
\text { for physician global } \\
\text { disease activity and } \\
\text { parents' overall well- } \\
\text { being, intolerant of or } \\
\text { failed } \geq 1 \text { of DMARD } \\
\text { and NSAID }\end{array}$ & No (SSZ allowed) & $\begin{array}{l}\text { Disease flare } \\
\text { during randomised } \\
\text { withdrawal phase }\end{array}$ & $\begin{array}{l}\text { Placebo: } 9 \text { of } 18 \text { vs } \\
\text { etanercept: } 3 \text { of } 20 \\
O R=6, P=0.02(95 \% \\
C l=1.1-37)\end{array}$ & 2 \\
\hline $\begin{array}{l}\text { Lovell, } \\
2008^{14}\end{array}$ & $\begin{array}{l}\text { 16-week open- } \\
\text { label lead-in phase, } \\
\mathrm{n}=171 \\
\text { 32-week } \\
\text { randomised } \\
\text { withdrawal phase } \\
\text { for those who } \\
\text { achieved ACR Pedi } \\
30, \mathrm{n}=144 \\
\text { Open-label } \\
\text { extension phase }\end{array}$ & $\begin{array}{l}\text { Adalimumab sc } \\
24 \mathrm{mg} / \mathrm{m}^{2} \text { every } \\
\text { other week, max } 40 \\
\mathrm{mg} \text { vs placebo } \\
\text { During open-label } \\
\text { extension: } \\
20 \mathrm{mg} \text { for } \mathrm{BW}<30 \\
\mathrm{~kg} ; 40 \mathrm{mg} \text { for } \mathrm{BW} \\
\geq 30 \mathrm{~kg}\end{array}$ & $\begin{array}{l}\text { pcJIA (any type of } \\
\text { onset) } \\
\text { Aged } 4-17 \text { years } \\
\text { Active disease: } \geq 5 \\
\text { swollen and } 3 \text { LOM, } \\
\text { inadequate response } \\
\text { to or intolerant of } \\
\text { NSAIDs with or } \\
\text { without } \pm \text { MTx }\end{array}$ & Allowed & $\begin{array}{l}\text { Disease flare } \\
\text { in those not } \\
\text { receiving MTx } \\
\text { during randomised } \\
\text { withdrawal phase }\end{array}$ & $\begin{array}{l}\text { Those not on MTx: } \\
\text { adalimumab } 13 / 30 \\
\text { (43\%) vs placebo } \\
20 / 28 \text { ( } 71 \%), P=0.03 \\
\text { Those on MTx: } \\
\text { adalimumab + } \\
\text { MTx } 14 / 38 \text { ( } 37 \%) \\
\text { vs placebo + MTx } \\
24 / 37(65 \%), P=0.02\end{array}$ & 2 \\
\hline $\begin{array}{l}\text { Burgos- } \\
\text { Vargas, } \\
2015^{15}\end{array}$ & 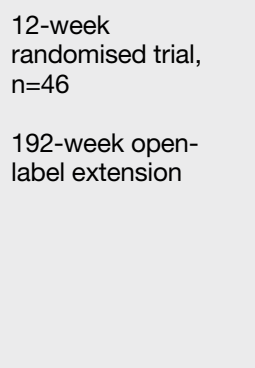 & $\begin{array}{l}\text { Adalimumab sc } \\
24 \mathrm{mg} / \mathrm{m}^{2} \text { every } \\
\text { other week } \\
\text { Max } 40 \mathrm{mg} \\
\text { vs placebo }\end{array}$ & $\begin{array}{l}\text { ERA, aged 6-17 } \\
\text { years } \\
\text { Active disease: } \geq 3 \\
\text { active joints and } \geq 1 \\
\text { enthesitis, inadequate } \\
\text { response to or } \\
\text { intolerant of } \geq 1 \\
\text { NSAID and } \geq 1 \\
\text { DMARD (SSZ/MTx) } \\
\text { (Active joint: swelling } \\
\text { or LOM) }\end{array}$ & $\begin{array}{l}\text { Allowed (SSZ also } \\
\text { allowed) }\end{array}$ & $\begin{array}{l}\text { Mean percentage } \\
\text { change in active } \\
\text { joint count from } \\
\text { baseline to week } 12\end{array}$ & $\begin{array}{l}\text { Adalimumab: } \\
-62.2 \% \text { vs placebo: } \\
-11.6 \%, P=0.039\end{array}$ & 2 \\
\hline
\end{tabular}

Abbreviations: $95 \% \mathrm{Cl}=95 \%$ confidence interval; $\mathrm{ACR}=$ American College of Rheumatology; $\mathrm{BW}=$ body weight ; DMARDs = disease-modifying antirheumatic drugs; eo|IA = extended oligoarticular JIA; ERA = enthesitis-related arthritis; $\mathrm{HCQ}=$ hydroxychloroquine; iv = intravenous; JIA = juvenile idiopathic arthritis; LOM = limitation in range of movement; MTx = methotrexate; NRS = numeric rating scale score; NSAIDs = nonsteroidal antiinflammatory drugs; OR = odds ratio; Pc IIA = polyarticular course JIA; PJIA = polyarticular JIA; PsA = psoriatic arthritis; sc = subcutaneous; SIIA = systemic JIA; SSZ = sulphasalazine

* OCEBM Level of Evidence Working Group. "The Oxford 20II Levels of Evidence". Oxford Centre for Evidence-based Medicine. (http://www.cebm.net/ index.aspx? $=5653$ ) 
TABLE I. (cont'd)

\begin{tabular}{|c|c|c|c|c|c|c|c|}
\hline $\begin{array}{l}\text { Author, } \\
\text { year }\end{array}$ & $\begin{array}{l}\text { Study design, } \\
\text { sample size, } \\
\text { duration }\end{array}$ & $\begin{array}{l}\text { Drugs, } \\
\text { comparator }\end{array}$ & Population & Concomitant MTx & Primary outcome & Results & $\begin{array}{c}\text { Level of } \\
\text { evidence* }^{*}\end{array}$ \\
\hline $\begin{array}{l}\text { Ruperto, } \\
2008^{17}\end{array}$ & $\begin{array}{l}\text { 16-week open- } \\
\text { label lead-in phase, } \\
n=190 \\
\text { 24-week } \\
\text { randomised } \\
\text { withdrawal phase } \\
\text { for those who } \\
\text { achieved ACR } 30 \text {, } \\
n=122 \\
\text { 5-year open-label } \\
\text { extension }\end{array}$ & $\begin{array}{l}\text { Abatacept } 10 \mathrm{mg} / \mathrm{kg} \\
\text { iv in over } 30 \text { mins } \\
\text { Max } 1 \mathrm{~g} \text {, on days } \\
1,15, \text { and } 29, \text { then } \\
\text { every } 28 \text { days } \\
\text { vs placebo }\end{array}$ & $\begin{array}{l}\text { pcJIA (eoJIA, PJIA, } \\
\text { SJIA without systemic } \\
\text { features) } \\
\text { Aged } 6-17 \text { years } \\
\text { At least } 5 \text { active } \\
\text { joints and active } \\
\text { disease (2 active and } \\
2 \text { LOM), inadequate } \\
\text { response or intolerant } \\
\text { of DMARDs including } \\
\text { anti-TNF }\end{array}$ & Allowed & $\begin{array}{l}\text { Time to flare } \\
\text { during randomised } \\
\text { withdrawal phase }\end{array}$ & $\begin{array}{l}\text { Significantly shorter } \\
\text { time to flare for } \\
\text { placebo } \\
\text { Placebo group: } \\
\text { median time } \\
6 \text { months vs } \\
\text { insufficient event } \\
\text { for abatacept, } \\
\mathrm{P}=0.0002 \\
\text { Risk of flare, } \\
\text { hazard ratio=0.31; } \\
95 \% \mathrm{Cl}=0.16-0.95\end{array}$ & 2 \\
\hline $\begin{array}{l}\text { Brunner, } \\
2015^{19}\end{array}$ & $\begin{array}{l}\text { 16-week open- } \\
\text { label lead-in phase, } \\
n=188 \\
\text { 24-week } \\
\text { randomised } \\
\text { withdrawal phase } \\
\text { for those who } \\
\text { achieved ACR } 30 \text {, } \\
n=163 \\
\text { 64-week open-label } \\
\text { extension phase }\end{array}$ & $\begin{array}{l}\text { Tocilizumab iv } \\
\text { BW <30 kg: } \\
\text { randomised to either } \\
8 \mathrm{mg} / \mathrm{kg} \text { or } 10 \mathrm{mg} / \\
\mathrm{kg} \text {, every } 4 \text { weeks } \\
\mathrm{BW} \geq 30 \mathrm{~kg}: 8 \mathrm{mg} / \\
\mathrm{kg}, \text { every } 4 \text { weeks } \\
\text { vs placebo }\end{array}$ & $\begin{array}{l}\text { pcJIA (PJIA, eoJIA) } \\
\text { Aged } 2-17 \text { years } \\
\text { At least } 5 \text { active joints } \\
\text { (swelling or LOM) } \\
\text { and LOM in } \geq 3 \text { active } \\
\text { joints } \\
\text { Inadequate response } \\
\text { to or intolerant of MTx } \\
\text { Previous use of } \\
\text { biologics was allowed }\end{array}$ & Allowed & $\begin{array}{l}\text { Disease flare } \\
\text { during randomised } \\
\text { withdrawal phase }\end{array}$ & $\begin{array}{l}\text { Placebo: } 39 / 81 \\
\text { (48.1\%) vs } \\
\text { tocilizumab: } 21 / 82 \\
(25.6 \%) \\
\text { Adjusted difference } \\
\text { in flare rate: }-0.21 ; \\
95 \% \mathrm{Cl}=-0.35 \text { to } \\
-0.08 \\
\mathrm{P}=0.0024\end{array}$ & 2 \\
\hline
\end{tabular}

\section{Systemic reviews of biologics}

The short-term efficacies of biologics have been confirmed by systemic reviews. ${ }^{20-22}$ While there have been no head-to-head trials between individual biologics, analysis with indirect comparisons has not shown obvious differences in efficacy. Longer-term data (mainly for etanercept) and reports from major registries also confirm biologics' effectiveness and safety. ${ }^{23}$ The results of clinical trials are summarised in Table 1.

\section{Statement 3: Eligibility criteria for using biological disease-modifying antirheumatic drugs}

The work group achieved overwhelming consensus on the following eligibility criteria.

\section{Eligible conditions, age, and biologics}

Table 2 lists the JIA subtypes and the corresponding biological DMARDs indicated. Anti-TNF inhibitors are usually the first biologics to commence, except in systemic JIA. The decision of which biologic to start also depends on JIA subtype, the presence of extraarticular manifestations (eg, uveitis, inflammatory bowel disease), patient preferences, etc. ${ }^{24,25}$

\section{Definition of adequate use of conventional disease-modifying antirheumatic drugs}

- Patients should have been treated with at least one cDMARD at adequate dose for at least 3 months unless toxicities are present.

- Use of intra-articular steroid injections or a short course of bridging systemic corticosteroids are acceptable during trial use of cDMARDs.

- In addition to cDMARDs, at least one anti-TNF inhibitor should have been tried before starting abatacept.

It usually takes 6 to 8 weeks before the effects of cDMARDs can be seen. "Adequate cDMARDs exposure" is often defined as at least 3 months. However, if one develops significant intolerance or toxicities during trial of cDMARDs, use of biologics should be considered earlier.

\section{Definition of persistently active disease}

- pcJIA: Five or more joints with active arthritis

- ERA and PsA: three or more joints with active arthritis

"Active arthritis" is defined as swelling, with or without limitation in movement. Joints with limitation in movement due to pain or tenderness are also considered as "active", especially those in which swelling is difficult to assess.

When deciding the number of joints required to define active disease, the work group adopted the commonly used inclusion criteria of the clinical trials. In view of the fact that the disease characteristics (eg, number of joints involved, clinical course, medication indicated) are somewhat different for 
ERA and PsA, the work group considered it more appropriate to have seperate definitions for ERA and PsA.

\section{Statement 4: Assessment of response}

- Assessment of response to biological DMARDs should be performed after adequate exposure. For etanercept, adalimumab and tocilizumab, assessment should take place at 16 weeks. For abatacept, assessment at 24 weeks is acceptable if the expected response is not reached by 16 weeks.

- A $50 \%$ reduction of the initial active joint count ( $\geq 2$ joints) is considered as a positive response.

Patients usually experience improvement within or around 3 months after commencement. The exception is abatacept, which may take a bit longer to achieve the desired therapeutic effect. ${ }^{20}$

The definition of positive response is extrapolated from Pharmaceutical Benefits Scheme. It is easy to apply and does not require inflammatory markers like erythrocyte sedimentation rate and Creactive protein, as they are not always elevated.

\section{Statement 5: Termination of treatment}

Termination of treatment should be considered in the following situations:

- Toxicities or medical conditions that contraindicate further use of biologics, including but not limited to severe injection reaction, severe infection, malignancy, demyelination, heart failure, etc

- Pregnancy (temporary withdrawal may be appropriate for anti-TNF inhibitors)

- Lack of $50 \%$ reduction in the number of joints with active arthritis after the 16th week (or 6 th month for abatacept)

- Persistent inactive disease state, defined as Clinical Juvenile Arthritis Disease Activity Score $\leq \mathbf{1}$, for at least 1 year

The above termination criteria represent the common "end points" for stopping biologics, ie, the development of side-effects, conditions contra-indicated for use of biologics, or continuous remission of the index disease.

Pregnancy is no longer an absolute contraindication in adult patients with rheumatoid arthritis or ankylosing spondylitis who are receiving antiTNF inhibitors. Temporary withdrawal, however, is necessary for some agents. There have been no recent updates from international organisations on the use of biologics in pregnant patients with JIA. This issue should be revisited during the next update.

Several definitions are used to describe treatment response and disease remission in JIA. ${ }^{26}$
TABLE 2. Eligibility: age, subtype, and biologics

\begin{tabular}{ll}
\hline JIA subtype & Biologics \\
\hline pcJIA $\geq 2$ years & $\begin{array}{l}\text { Etanercept } \\
\text { Adalimumab } \\
\text { Tocilizumab (eoJIA, PJIA) }\end{array}$ \\
$\begin{array}{ll}\text { pcJIA who fail to response to } \geq 1 \text { cDMARD and } \geq 1 \\
\text { anti-TNF inhibitor, aged } \geq 6 \text { years (including eoJIA, } \\
\text { PJIA, SJIA without active systemic features) }\end{array}$ & Abatacept \\
ERA $\geq 12$ years & \\
ERA $\geq 6$ years & Etanercept, adalimumab \\
PsA $\geq 12$ years & Adalimumab \\
\hline
\end{tabular}

Abbreviations: cDMARDs = conventional disease-modifying antirheumatic drugs; eojIA $=$ extended oligoarticular IIA; ERA = enthesitis-related arthritis; $\| \mathrm{A}=$ juvenile idiopathic arthritis; $p c \| A=$ polyarticular course $\|\mathrm{A} ; \mathrm{P}\| \mathrm{A}=$ polyarticular $\| \mathrm{A} ; \mathrm{Ps} \mathrm{A}=$ psoriatic

arthritis; SJIA = systemic JIA;TNF = tumour necrosis factor

The Clinical Juvenile Arthritis Disease Activity Score is a composite measurement that evaluates three variables: active joint count, patient's/parents' global well-being score, and physician's global disease activity score (both on visual analogue scales). It has been shown to outperform other activity measurements in predicting the need of escalation to anti-TNF inhibitors. ${ }^{27}$ For both oligoarticular arthritis and pcJIA, a score of $\leq 1$ signifies inactive disease.

\section{Statement 6: Malignancy and infection}

- The risk of developing new-onset malignancy due to exposure to biological DMARDs is low. Careful screening and close monitoring are recommended.

- Patients on biological DMARDs should follow vaccination schedules according to local recommendations except for live attenuated vaccines. Infection screening should be performed prior to commencement. Screening should include (but not be limited to) tuberculosis, hepatitis $B$ and $C$. Individual risk profiles should also be taken into consideration.

In 2008, the FDA issued a black box warning about the development of malignancy, particularly lymphoproliferative types, in 48 children after commencement of anti-TNF inhibitors between 2001 and 2008. ${ }^{28}$ In recent years, researchers investigated the risk of malignancy by analysing data generated from major registries and medical reimbursement databases. These data suggested that TNF inhibition alone is probably not causing the apparent increase in incident malignancy. Instead, those children's background risk might have already been elevated compared with that of the general population. Nevertheless, much longer-term data on larger patient samples are needed, as both cancer and JIA are rare in children. ${ }^{29-31}$ 
Data on the associations between malignancy and other non-anti-TNF biologics are still lacking. Careful screening prior to commencement and ongoing surveillance are necessary.

As for infection, biological DMARDs are generally safe. Most infections associated with the use of biologics are mild. Nevertheless, data from registries and medical insurance databases did show an increase in bacterial or serious infections associated with TNF inhibition. ${ }^{32-34}$ Tuberculosis is a genuine concern in our locality. ${ }^{35,36}$ Careful screening and follow-up according to individual risk profiles is strongly encouraged. The baseline infection screening should include, but not be limited to, the following:

- Tuberculosis: Mantoux test, chest X-ray, interferon-gamma release assay

- Hepatitis screening: hepatitis B surface antigen, antibody to hepatitis B core antigen, antibody to

\section{hepatitis $\mathrm{C}$ antigen}

While live attenuated vaccines should be avoided during use of biologics, patients should follow local guidelines for non-live vaccines.

\section{Statement 7: Special consideration}

- For patients with refractory disease but who do not fulfil the above criteria, biologics can be considered on a case-by-case basis.

The work group is aware that some patients who do not fulfil the above criteria might still benefit from biologics. These patients include those with persistently active and disabling multiple enthesitis or sacroiliitis despite NSAIDs and DMARDs or oligoarticular JIA with severely active arthritis and has exhausted treatment modalities including intra-articular steroid injections and multiple cDMARDs, etc. The use of biologics can be

TABLE 3. Summary of key consensus

\section{Consensus statements}

Statement 1: Level of care

Care of children with JIA should preferably be shared jointly with paediatricians experienced in managing JIA.

Statement 2: Therapeutic ladder

For pcJIA, ERA and PsA, patients with persistently active arthritis despite adequate use of $\geq 1 \mathrm{cDMARD}$, or if patients are intolerant of them, treatment escalation to biological DMARDs should be considered.

Statement 3: Eligibility criteria for using biological DMARDs

(a) Eligible conditions, age, and biologics

- pcJIA aged $\geq 2$ years: etanercept, adalimumab, tocilizumab (eoJIA, PJIA)

- pcJIA (including eoJIA, PJIA, SJIA without active systemic features) who fail to response to $\geq 1$ DMARD and $\geq 1$ anti-TNF inhibitor, aged $\geq 6$ years: abatacept

- ERA: adalimumab (aged $\geq 6$ years), etanercept (aged $\geq 12$ years)

- PsA: etanercept (aged $\geq 12$ years)

(b) Definition of adequate cDMARD use

- Patient should have been treated with $\geq 1 \mathrm{cDMARD}$ at adequate dose for $\geq 3$ months unless toxicities are present.

- Use of intra-articular steroid injections or a short course of bridging systemic corticosteroids are acceptable during trial use of cDMARDs.

- In addition to cDMARDs, $\geq 1$ anti-TNF inhibitor should have been tried before starting abatacept.

(c) Definition of persistently active disease

- pcJIA: $\geq 5$ joints with active arthritis

- ERA and PsA: $\geq 3$ joints with active arthritis

Statement 4: Assessment of response

- Assessment of response to biological DMARDs should be performed after adequate exposure. For etanercept, adalimumab and tocilizumab, assessment should take place at 16 weeks. For abatacept, assessment at 24 weeks is acceptable if the expected response is not reached by 16 weeks.

- A $50 \%$ reduction in the initial active joint count ( $\geq 2$ joints) is considered as a positive response.

Statement 5: Termination of treatment

Termination of treatment should be considered in the following situations:

- Toxicities or medical conditions that contra-indicate further use of biologics (including but not limited to severe injection reaction, severe infection, malignancy, demyelination, heart failure, etc)

- Pregnancy (temporary withdrawal may be appropriate for anti-TNF inhibitors)

- Lack of $50 \%$ reduction in the number of joints with active arthritis after the 16th week (or 6th month for abatacept)

- Persistent inactive disease state, defined as CJADAS $\leq 1$, for $\geq 1$ year

Statement 6: Malignancy and infection

- The risk of developing new-onset malignancy due to exposure to biological DMARDs is low. Careful screening and close monitoring are recommended.

- Patients on biological DMARDs should follow local recommendations for vaccination practices except for live attenuated vaccines. Infection screening should be performed prior to commencement. Screening should include (but not be limited to) tuberculosis and hepatitis B and C. Individual risk profiles should be taken into consideration.

Statement 7: Special consideration

For patients with refractory disease but who do not fulfil the above criteria, biologics can be considered on a case-by-case basis.

Abbreviations: cDMARDs = conventional DMARDs; cJADAS = Clinical Juvenile Arthritis Disease Activity Score; DMARDs = disease-modifying antirheumatic drugs; eo IIA = extended oligoarticular JIA; ERA = enthesitis-related arthritis; IIA = juvenile idiopathic arthritis; pc IIA = polyarticular course JIA; PJIA = polyarticular JIA; PsA = psoriatic arthritis; SJIA = systemic JIA 


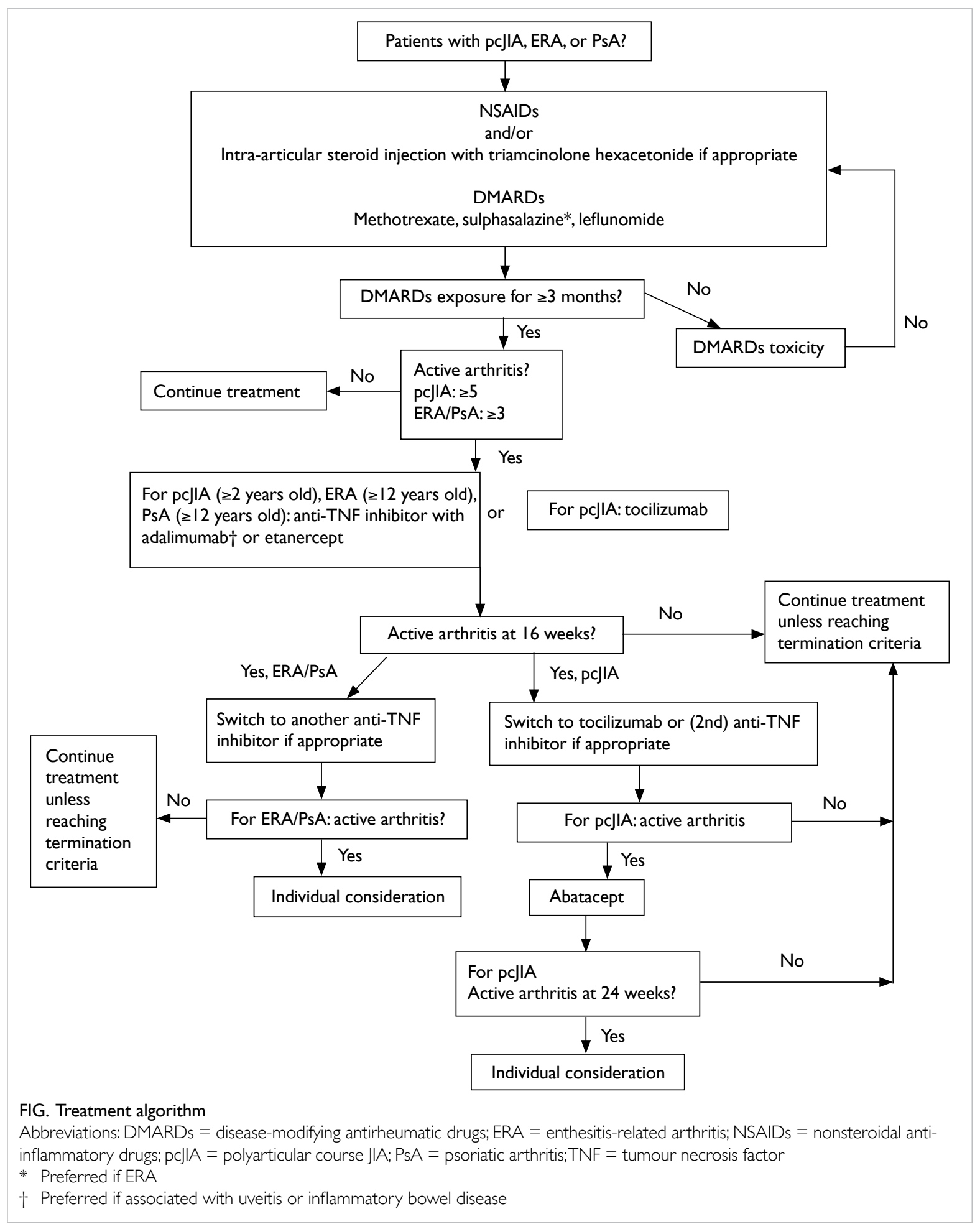

considered after careful assessment on a case-by- abatacept and tocilizumab are approved for pcJIA in case basis. patients aged $\geq 2$ years in the United States. ${ }^{37-39}$ The

The key recommendations and treatment ACR is also preparing a new update of the 2011 and algorithm are summarised in Table 3 and the Figure. 2013 guidelines. A review of the practice should be

\section{Looking ahead: new indications} after the review period performed regularly.

The indications for use of biological DMARDs Conclusion

have been expanding. For example, subcutaneous

The use of biological DMARDs has greatly improved the management of patients with JIA. Both patients 
and physicians could benefit from incorporating the latest and best available evidence into disease management. Periodic review should be performed to keep clinical practice evidence-based and up-todate.

\section{Author contributions}

All the authors contributed substantially to conception and design, acquisition and analysis of data, drafting and revising the article, and approval of the version to be published.

\section{Conflicts of interest}

All authors have no competing interest in the products mentioned in this paper.

\section{Funding/support}

This research received no specific grant from any funding agency in the public, commercial, or not-for-profit sectors.

\section{References}

1. Lee TL, Lau YL, Chan W, et al. Juvenile idiopathic arthritis in Hong Kong and its current management. HK J Paediatr (new series) 2003;8:21-30.

2. Guzman J, Oen K, Tucker LB, et al. The outcomes of juvenile idiopathic arthritis in children managed with contemporary treatments: results from the ReACCh-Out cohort. Ann Rheum Dis 2015;74:1854-60.

3. Giannini EH, Brewer EJ, Kuzmina N, et al. Methotrexate in resistant juvenile rheumatoid arthritis. Results of the U.S.-U.S.S.R. double-blind, placebo-controlled trial. The Pediatric Rheumatology Collaborative Study Group and The Cooperative Children's Study Group. N Engl J Med 1992;326:1043-9.

4. Woo P, Southwood TR, Prieur AM, et al. Randomised placebo-controlled, crossover trial of low-dose oral methotrexate in children with extended oligoarticular or systemic arthritis. Arthritis Rheum 2000;43:1849-57.

5. Silverman E, Mouy R, Spiegel L, et al. Leflunomide or methotrexate for juvenile rheumatoid arthritis. $\mathrm{N}$ Engl J Med 2005;352:1655-66.

6. van Rossum MA, Fiselier TJ, Franssen MJ, et al. Sulfasalazine in the treatment of juvenile chronic arthritis: a randomised, double-blind, placebo-controlled, multicenter study. Dutch Juvenile Chronic Arthritis Study Group. Arthritis Rheum 1998;41:808-16.

7. Lovell DJ, Giannini EH, Reiff A, et al. Etanercept in children with polyarticular juvenile rheumatoid arthritis. Pediatric Rheumatology Collaborative Study Group. N Engl J Med 2000;342:763-9.

8. Lovell DJ, Reiff A, Ilowite NT, et al. Safety and efficacy of up to eight years of continuous etanercept therapy in patients with juvenile rheumatoid arthritis. Arthritis Rheum 2008;58:1496-504.

9. Horneff G, Burgos-Vargas R, Constantin T, et al. Efficacy and safety of open-label etanercept on extended oligoarticular juvenile idiopathic arthritis, enthesitisrelated arthritis and psoriatic arthritis: part 1 (week 12) of the CLIPPER study. Ann Rheum Dis 2014;73:1114-22.

10. Horneff G, Foeldvari I, Minden K, et al. Efficacy and safety of etanercept in patients with the enthesitis-related arthritis category of juvenile idiopathic arthritis. Arthritis
Rheumatol 2015;67:2240-9.

11. Windschall D, Horneff G. Safety and efficacy of etanercept and adalimumab in children aged 2 to 4 years with juvenile idiopathic arthritis. Clin Rheumatol 2016;35:2925-31.

12. Horneff G, Ebert A, Fitter S, et al. Safety and efficacy of once weekly etanercept $0.8 \mathrm{mg} / \mathrm{kg}$ in a multicenter 12 week trial in active polyarticular course juvenile idiopathic arthritis. Rheumatology (Oxford) 2009;48:916-9.

13. Horneff G, De Bock F, Foeldvari I, et al. Safety and efficacy of combination of etanercept and methotrexate compared to treatment with etanercept only in patients with juvenile idiopathic arthritis (JIA): preliminary data from the German JIA Registry. Ann Rheum Dis 2009;68:519-25.

14. Lovell DJ, Ruperto N, Goodman S, et al. Adalimumab with or without methotrexate in juvenile rheumatoid arthritis. N Engl J Med 2008;359:810-20.

15. Burgos-Vargas R, Tse SM, Horneff G, et al. A randomized, double-blind, placebo-controlled multicenter study of adalimumab in pediatric patients with enthesitis-related arthritis. Arthritis Care Res (Hoboken) 2015;67:1503-12.

16. Kingsbury DJ, Bader-Meunier B, Patel G, Arora V, Kalabic J, Kupper H. Safety, effectiveness, and pharmacokinetics of adalimumab in children with polyarticular juvenile idiopathic arthritis aged 2 to 4 years. Clin Rheumatol 2014;33:1433-41.

17. Ruperto N, Lovell DJ, Quartier P, et al. Abatacept in children with juvenile idiopathic arthritis: a randomized, double-blind, placebo-controlled withdrawal trial. Lancet 2008;372:383-91.

18. Ruperto N, Lovell DJ, Quartier P, et al. Long-term safety and efficacy of abatacept in children with juvenile idiopathic arthritis. Arthritis Rheum 2010;62:1792-802.

19. Brunner HI, Ruperto N, Zuber Z, et al. Efficacy and safety of tocilizumab in patients with polyarticular-course juvenile idiopathic arthritis: results from a phase 3, randomized, double-blind withdrawal trial. Ann Rheum Dis 2015;74:1110-7.

20. Shepherd J, Cooper K, Harris P, Picot J, Rose M. The clinical effectiveness and cost-effectiveness of abatacept, adalimumab, etanercept and tocilizumab for treating juvenile idiopathic arthritis: a systematic review and economic evaluation. Health Technol Assess 2016;20:1222.

21. Ungar WJ, Costa V, Burnett HF, Feldman BM, Laxer RM. The use of biologic response modifiers in polyarticularcourse juvenile idiopathic arthritis: a systematic review. Semin Arthritis Rheum 2013;42:597-618.

22. Otten MH, Anink J, Spronk S, van Suijlekom-Smit LW. Efficacy of biological agents in juvenile idiopathic arthritis: a systematic review using indirect comparisons. Ann Rheum Dis 2013;72:1806-12.

23. Klotsche J, Niewerth M, Haas JP, et al. Long-term safety of etanercept and adalimumab compared to methotrexate in patients with juvenile idiopathic arthritis (JIA). Ann Rheum Dis 2016;75:855-61.

24. Anink J, Otten MH, Gorter SL, et al. Treatment choices of paediatric rheumatologists for juvenile idiopathic arthritis: etanercept or adalimumab? Rheumatology (Oxford) 2013;52:1674-9.

25. Kearsley-Fleet L, Davies R, Baildam E, et al. Factors associated with choice of biologics among children with juvenile idiopathic arthritis: results from two UK paediatric biologic registers. Rheumatology (Oxford) 2016;55:1556- 
65.

26. Smith EM, Foster HE, Beresford MW. The development and assessment of biological treatments for children. Br J Clin Pharmacol 2015;79:379-94.

27. Swart JF, van Dijkhuizen EH, Wulffraat NM, de Roock S. Clinical juvenile arthritis disease activity score proves to be a useful tool in treat-to-target therapy in juvenile idiopathic arthritis. Ann Rheum Dis 2018;77:336-42.

28. Diak P, Siegel J, La Grenada L, Choi L, Lemery S, McMahon A. Tumor necrosis factor alpha blockers and malignancy in children: forty-eight cases reported to the Food and Drug Administration. Arthritis Rheum 2010;62:2517-24.

29. Beukelman T, Haynes K, Curtis JR, et al. Rate of malignancy associated with juvenile idiopathic arthritis and its treatment. Arthritis Rheum 2012;64:1263-71.

30. Ruperto N, Martini A. Juvenile idiopathic arthritis and malignancy. Rheumatology (Oxford) 2014;53:968-74.

31. Mannion ML, Beukelman T. Risk of malignancy associated with biologic agents in pediatric rheumatic disease. Curr Opin Rheumatol 2014;26:538-42.

32. Beukelman T, Xie F, Chen L, et al. Rates of hospitalized bacterial infection associated with juvenile idiopathic arthritis and its treatment. Arthritis Rheum 2012;64:277380 .

33. Davies R, Southwood TR, Kearsley-Fleet L, Lunt M, Hyrich KL; British Society for Paediatric and Adolescent Rheumatology Etanercept Cohort Study. Medically significant infections are increased in patients with juvenile idiopathic arthritis treated with etanercept: results from the British Society for Paediatric and Adolescent Rheumatology Etanercept Cohort Study. Arthritis Rheumatol 2015;67:2487-94.

34. Becker I, Horneff G. Risk of serious infection in juvenile idiopathic arthritis patients associated with tumor necrosis factor inhibitors and disease activity in the German biologic in pediatric rheumatology registry. Arthritis Care Res (Hoboken) 2017;69:552-60.

35. Mok CC, Tam LS, Chan TH, Lee GK, Li EK; Hong Kong Society of Rheumatology. Management of rheumatoid arthritis: consensus recommendations from the Hong Kong Society of Rheumatology. Clin Rheumatol 2011;30:30312.

36. Wan R, Mok CC. The Hong Kong Society of Rheumatology Biologics Registry: Updated Report (May 2016). HK Bulletin Rheum Dis 2016;16:24-6.

37. Brunner HI, Tzaribachev N, Vega-Cornejo G, et al. Subcutaneous abatacept in patient with polyarticularcourse juvenile idiopathic arthritis: results from a phase III open-label study. Arthritis Rheumatol 2018;70:1144-54.

38. Brunner H, Ruperto N, Martini A, et al. Identification of optimal subcutaneous doses of tocilizumab in children with polyarticular course juvenile idiopathic arthritis. Arthritis Rheumatol 2017;69(Suppl 4):Abstract 41.

39. De Benedetti F, Ruperto N, Lovell D, et al. THU0503 identification of optimal subcutaneous (SC) doses of tocilizumab in children with polyarticular-course juvenile idiopathic arthritis (PCJIA). Ann Rheum Dis 2017;76(Suppl 2):396. 